Валентина Питулић

Филозофски факултет

Косовска Митровица

valentina.pitulic@pr.ac.rs
398:821.163.41.09-31 Андрић И. https://doi.org/10.18485/ai_most.2017.ch7

\title{
ГРАДЊА МОСТА И ЖРТВЕНИ ОБРЕД У РОМАНУ НА ДРИНИ ЋУПРИЈА ИВА АНДРИЋА
}

Жртвени обред је устаљена радња која је утицала на опстанак грађевине у свим древним цивилизацијама. Иво Андрић у роману На Дрини ћуйрија кореспондира са остацима архаичних слојева у колективно-несвесном градитеља моста и на тај начин уводи у роман митолошке слојеве који имају важну улогу у концепцији савладавања воде и спајања две обале.

Показаћемо колико је жртвени обред, као кључни моменат у животу словенског народа, имао утицаја на опстанак моста. Жртвени обред, као комплексна радња, подлеже строго одређеним правилима која се морају поштовати да би се грађевина одржала. Показаћемо да ли је у роману На Дрини ћуйрија писац транспоновао већ готов модел жртвеног обреда који је дуго живео у колективној свести Срба. У раду ћемо се бавити оним слојевима који су утицали на градњу моста, налазе се у подтексту, тешко су препознатљиви, а чине нераскидиви део обреда који утиче на опстанак грађевине.

Кључне речи: жртва, обред, мост, Дрина, иницијација, грађевина, колектив, јунак.

О мотиву моста, не само у Андрићевом роману $\mathrm{Ha}$ Дрини ћуйрија, већ и уопште, писано је са различитих становишта. Мост као грађевина представља место опасног преласка и на њему, како каже Елијаде „обилују погребне 
свечаности и иницијатички обреди“. (Елијаде 2003: 192) Потреба да се премости граница и овлада тајним силама стара је колико и човечанство. У свим древним културама постоји стална борба између светлости и таме, добра и зла, соларног и хтонског. „Супротност светлост-тама“ како наводи Ерих Нојман, „одређивала је и обликовала духовни свет свих народа“, (Нојман 1994: 92). Питање које нам се намеће је да ли је могуће градњу моста на Дрини ставити на матрицу жртвеног обреда, које је, како каже Мирча Елијаде „само подражавање, често симболичко, првобитне жртве која је родила Свет“. (Елијаде 2003: 101) Ако тачку гледишта поставимо на позицију допуштења виших сила да се нешто оствари, отелотвори и оптредмети, онда нам се даје могућност да све оно што се догађа у току градње моста ставимо на фон обредних радњи (Генеп 2005: 5-22) које су почетак свих древних цивилизација и свих грађевина којима човек има намеру да овлада.

Мост ћемо посматрати као грађевину која би требало да савлада препреку, односно границу - воду. ${ }^{1}$ У свим древним цивилизацијама вода је имала своје законитости, она се „у нашем народу замишља као свако живо биће“ (СМР 1986: 72) од чије је ћуди зависило све што се догађа око ње. Свака градња повезана је са савладавањем простора, пре свега налажење тачке ослонца, а то је земља, која мора бити савладана да би се грађевина одржала. Џејмс Џорџ Фрејзер каже да су сви народи света у

\footnotetext{
"У нашем народу се вода замишља као свако живо биће. Она се у обредима поздравља и позива: „Водице, по богу сестрице, однеси моје грознице“. Приликом вађења мазије (гвожђа) из вреле воде, свештеник се обраћа води: „Водо, кумим те небом и преклињем земљом, поштеди праву душу од живога огња“ (мазије). Када вода пред кључање почне да зуји, онда треба уклонити с ватре, да се не би „мучила“. Пошто се вода унесе у кућу спусти се на земљу „да се одмори“, па се онда пије“. Срйски митиолочки речник, Ш. Кулишшћ, П.Ж. Петровић, Н. Пантелић, Нолит, Београд, 1970, стр. 72.
} 
свом развоју „покушавали да приморају природне силе да испуњавају њихове жеље, пре него што су мислили да њихову наклоност задобију приношењем жртава и молитвама“. (Фрејзер 1992: 78) Земља, као Велика мајка која прима у своја недра човека, животиње и биљке, биће други принцип који ћемо пратити у роману На Дрини ћyйрија. Ваздух, у којем, по веровању древних Словена ,обитавају добре и зле силе, такође има одређену функцију у систему обредних радњи, И на крају, ватра, која је у народном веровању „имала апотропејску и лустративну моћ против мистичних сила“ (СМР 1986: 55), али и важну улогу у процесу приношења жртве где у славу богова гута најбоље што је човек имао да подари.

Поћи ћемо од тога да је приношење жртве био древни обред старих Словена (Јанићијевић 1986: 178), а услов сваког обреда жртвовања је да се обави по строго одређеном правилу. У роману постоји скривени ритуал жртвовања где је у потребно, како наводи Миодраг Павловић, једном „да жртва буде женског пола, да појача женствени карактер елемената коме се жртва обраћа (земља, вода), други пут мушкарац, у пуној снази, да директно оплоди материнско тело тла“. (Павловић 1987: 63) Прво, увек се жртвује мушки и женски принцип, као две поларности на којима почива свет. Друго, ако се жртвују мушко и женско, не смеју бити муж и жена, не смеју ни момак и девојка, искључиво брат и сестра. Ако се жртвује мушкарац мора бити младић, ако је девојка, мора бити девица. Миодраг Павловић каже да жртва мора бити најбољи представник рода, али мора бити добровољна. Да би једна грађевина, каже Мирча Елијаде, била трајна, „она мора бити дотакнута, мора да прими истовремено живот и душу. Трансфер душе могућ је само путем крваве жртве“. (Елијаде, стр. 101)

Андрић на почетку романа позиционира хтонска и сакрална места, прави опозицију светла и таме. (Елијаде, стр. 105) Каже да „из привидно затвореног склопа црних 
и стрмих планина, стоји велики, складно срезани мост од камена“. (Андрић 1988: 105) У народној традицији планина је обитавалиште злих сила, хтонски простор који је и код Андрића „складно срезан мост“, док се предео око моста слика као „жупни и питоми простор“. (Андрић, стр. 105) Већ на самом почетку све што је око моста припада питомом простору који је отет од хаоса и мрачних планина које су око њега, а сваки простор који човек настањује је „симболички претвара у Космос, помоћу ритуалног понављања космогоније.. (Елијаде 2003: 83) На самом почетку романа Андрић почиње приповедање о настајању, савладавању, успостављању хармоније, и није могао да се негде у првом плану градње не дотакне жртвеног обреда. Андрић је био на трагу Елијадеовог поимања настањивања простора: „Било да се ради о крчењу неке необрађене територије или о победи и заузимању територије, коју већ настањују „друга људска бића, њено запоседање у сваком случају мора да понови космогонију. Извесна територија постаће „својом“ тек пошто се изнова 'створи' то јест пошто се сакрализује“. (Елијаде, 2003: 83) Шта би то значило у случају градње моста? Значило би да је потребно обновити космогонију, односно, да је потребно поновити све радње које су се обављале у прво време, када је грађен први мост и када се територија моста први пут сакрализовала, а то је обавезно, и у свим културама подразумевало приношење жртве.

Нећемо овом приликом улазити у систем жртвовања у хришћанској и исламској религији, односно религији главног актера Абидаге и хришћана. Поћи ћемо од кључне препреке у градњи моста, а то је кроћење воде и спајање две обале. Андрић у радњу уводи вилу, а виле су, како наводи Чајкановић „примиле на себе функцију многих различитих женских демона, шумских и пољских, 'водних' и 'метеорних', манистичких и 'природних', најмоћнијих и најнезнатнијих, локалних и општих“. (Чајкановић 1994: 228) Како је вилама „омиљено састајалиште“ како наводи Слободан 
Зечевић, „око вода или у облацима“ (Зечевић 2007: 46) то ће Андрић из народне традиције транспоновати у роман већ обликовану представу о овом женском демону. Вила бродарица, која руши мост, општепознати је симбол у словенској митологији, која, по строго одређеним правилима жртвовања, тражи „двоје нејаке деце, близнади, брата и сестру, Стоју и Остоју по имену, и да их узида у средње стубове моста“. (Андрић 1991: 108) Вила бродарица, која влада водом, захтева да буду уграђени не било како, већ „у средње стубове моста“. Средњи стуб моста није изабран произвољно, већ је то праслика космичког стуба који се налази у центру Универзума око кога се пружа цео настањен свет. (Елијаде 2003: 87) Древни дух воде замењен је млађим, у традицији манистичким демоном, вилом, која поставља услове градње, а то је жртва у људском облику. ${ }^{2}$ Међутим у исто време иде и жртва у другом смеру. За тренутак се напушта систем сакралног жртвовања Оном светиу самом констатацијом писца да је „обећана награда ономе ко их нађе и доведе. (Андрић 1991: 108) Андрић овде уводи и категорију даривања, која је у српској народној традицији такође симболична замена за жртву. Писац уводи у радњу близанце, али мртворођене, који су нека врста симболичне замене за право жртвовање које захтева вила. Слика мајке, како су је прозвали луде Илинке, која са дојкама набреклим од млека тражи децу око моста, подсећа на Велику мајку која је инстиктивно посвећена животу и рађању. Она (као Гојковица у балади 3ugaюе Скаgра) није узидана у зидове моста, и није принета на жртву, али сам њен долазак на мост и присуство смрти двоје њене деце има предзнак симбо-

2 „Жртве при грађењу зависе од типа космогонијских митова. Да би једна „грађевина“ (кућа, храм, техничка творевина итд.) била трајна, она мора бири дотакнута, мора да прими истовремено живот и душу. „Трансфер“ душе могућ је само преко крваве жртве.“ Мирча Елијаде, Светио и йрофано, Издавачка књижница Зорана Стојановића, Сремски Карловци, Нови Сад, 2003, стр. 101. 
личне замене за праву жртву. Како обредна жртва ипак није обављена, градња моста се наставља.

Градња моста се одвија на граници хтонских и соларних сила и писац, поред демонских бића из митолошке сфере, фокусира и реална бића која у епској традицији имају обележје хтонског (попут бабе, Арапа, Цигана). У стубу се, рецимо, налази мрачна соба где „живи црни Арапин“ који, како наводи Петар Џаџић, „одговара ритуалној мирској жртви којој је и намењено место у самом средишту градње“. (Џаџић 1991: 35) Ако узмемо причу о Арапину као предео хтонског, како га је Андрић и позиционирао, и њему је на неки начин принета жртва, али не у облику деце, већ одраслог мушкарца, Хамида. („Онако сипљиви и вечито пијани или мамурни Хамал крвавих очију, а умро је још те ноћи, ту поред зида“. (Андрић 1991: 109) Ово је трећа жртва на самом почетку градње моста. Ако је Арапин асоцијација хтонског, онда је, условно речено, Арапину, као симболу мрачних предела, жртвован пијани човек, крвавих очију, који има атрибуте „изокренуте стварности“.

Симболична замена за жртву је и прича о огромним јунацима који суу древним временима прескакали Дрину, ту где је сада мост. За Србе је то био Краљевић Марко, а за муслимане Ђерзелез Алија. Крилати коњи и јунаци позајмљени су из народне традиције. ${ }^{3}$ Они у роману прескачу Дрину савладавајући простор воде, где по древном веровању обитава божанство. И Марко Краљевић и Ђерзелез Алија у роману не припадају историјском вре-

„Гигантски раст, неизмерна снага, именовање девојке и њено везивање за простор горе, доста јасно асоцирају (већ поменута предања) и представе о „старом народу“ дуговеком поколењу дивовског раста и изузетне снаге, које је насељавало свет у почетку времена када је још „камен био мекан“. Лидија Делић, „Сукоб јунака с џиновком у јужнословенској усменој епици“, у

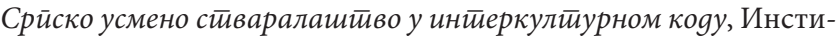
тут за књижевност и уметност, Београд, 2012, стр. 206. 
мену. Андрић уводи категорију древних времена, када су живели велики јунаци и „камен је још био незрео и мек као земља, а коњи су били, као и јунаци, џиновског раста“. (Андрић 1991: 110) Писац уводи категорију правремена, где је простор земље још необликован. Камен je, како каже, „још незрео и мек као земља“, и на трагу је констатације Миодрага Павловића да су „ране мистерије камена (су) боље сачуване од других“. (Павловић 1984: 20) Уз овај занимљив податак да је камен био „мек као земља“, као важан моменат у космогонији камена, односно моста, матрица обредне жртве постаје јаснија. Наиме, камен је прво требало створити, а он се неприметно обликује кроз лагано увођење у поетику жртвеног обреда. Џиновски јунаци прескачу реку на својим коњима чија је „сложена симболика (коња) оформљена (је) и потврђена динамичним функцијама још у обредном систему и митологији“. (Самарџија 2008: 59) Митски јунаци, које Андрић смешта у неисторијско време, савладавају препреку која је у свим древним цивилизацијама била предуслов за овладавање простором.

Лагано савладавање снаге воде, после обреда прескакања када се она задржавала у траговима копита коња, на неки начин представља кроћење њене снаге. У те мале јаме скупљала се вода од кише и она је постајала питома и служила је деци да „у њима држе, и једни и други, без разлике веровања, ситну рибу, кркушице и плоте, које ухвате на удицу“. (Андрић 1991: 110) На микроплану, вода је савладана преко обредне радње прескакања Дрине. На овај начин дошло је до симболичног жртвовања. Овладавање водом на микроплану има елементе имитативне магије где се прво овладава простором на малом узорку, да би се касније пренело и на макроплан.

У словенској митологији Велика мајка, Земља, има правила свог бивствовања. Земља, односно обала која би требало да прихвати мост, у роману је приказана као хтонски 
простор. Наиме, у земљи која је на левој обали, дакле лева, у народној традицији ђавоља страна, „ништа не расте и не цвате до нека ситна трава, тврда и бодљикава као челична жица“. (Андрић, 1991: 110) На левој страни налази се и хумка Радисава, кога Андрић слика као силовитог, необичног човека кога није „била ни пушка ни сабља“ и кога су убили на спавању, а после се на том месту, „између Велике и Мале Госпојине“ појављивала јака бела светлост. Ако се вратимо поетици жртвеног обреда земљи је жртвован мушкарац, а задовољено је и правило жртвовања да буде најбољи представник рода. Радисав, који је био неукротив и несавладив, представља жртву која испуњава све услове жртвеног обреда и на тај начин утиче на оплемењавање и лагано савладавање хтонског простора обале.

У обредној пракси Словена игра, песма, покрет, односно плес, представљају симболичну замену за жртву и није нимало случајно што се на мосту, по правилу, заустављају сватови да, како каже Андрић „ако су мирна и безбрижна времена, обредају се ракијом и запевају, поведу коло, и често се задрже много дуже него што су мислили“. (Андрић, 1991: 112) Овде је сватовска иницијација постављенаа на централно место, средишње место моста. На тај начин, писац је на фону народне традиције ишао у правцу разрешавања жртвеног обреда уз жртвовање невесте. И код погреба се поворка задржава дуже на капији, што је, такође, у служби приношења жртве у последњем обреду прелаза. Свако прелажење преко граница светова (две обале Дрине) представља аналогију између рађања и умирања, у овом случају умирања и свадбе, као две блиске иницијације. Блискост сватовског ритуала са погребним обредом (Зечевић 1982: 32-33) и код Андрића је имала кључну улогу. У систем обредне жртве уклапа се и жртвовање дечака у данку у крви, који су, по правилу, најбољи представници рода. Радови на мосту почели су после велике сече шума, као жртвовање 
вегетације. У води су пободени дрвени диреци, градња је почела, појединац и колектив се жртвују у тешком раду, али ни треће године градња моста не одмиче.

Слика осиромашеног и уморног народа се продужава. Занимљиво је да Андрић повремено фокусира народ који спава у својим појатама, а који се „одмара (се) и обнавља снагу“. (Андрић, 1991: 127) У градњу моста уграђена је појединачна, али и колективна жртва. Део симболичне колективне жртве је и слика гуслара који преко певања епске песме приноси жртву прецима који су важан моменат у градњи моста и који представља неку врсту „клицања предака“ (Чајкановић 1994: 116) јер се преко гуслања призива не само јунак из херојских времена, већ и снага предака који су своје колективно несвесно и архетипско уткали у песму. Црногорац песмом о цару Душану постиже неку врсту ритуалне жртве, која је у том тренутку уродила плодом, јер је на лицима слушалаца изазвала трансформацију, „сви трепћу удивљени и заблештени“. (Андрић, 1991: 128) Ова симболична замена за жртву ишла је у правцу тренутног отелотворења јер слушаоци реагују телом, али улазе и у једну потпуно нову стварност, готово сакралну, јер постају неосетљиви за све око себе, „прате песму као сопствену, лепшу и светлију судбину“. (Андрић, 1991: 128)

Жртвовање Радисава било је кључно зато што је било сурово, несвакидашње и уклапа се у обредност жртвовања најбољих, јер је човек, како би рекао Миодраг Павловић „као жртва племенит и узвишен“. (Павловић 1987: 62) После рушења радова посао не одмиче, али после извесног времена радови на копну напредују, не и они изнад воде. Као да није обредно испуњено све што је захтевало правило жртвовања. Има нечег обредно-сакралног у овој иконичној жртви. Андрић каже да су сејмени подстицали ватру која се распламсала. „Цела просторија је сјала, загрејана и свечана“. (Андрић, 1991: 141) Овај детаљ 
подсећа на жртвовање на словенским светилиштима, жртвовање ватром, односно спаљивањем, или чишћење простора као део традиције словенских народа. (Тројановић 1990: 189-192) Радисав ће бити важна карика у обредном систему жртвовања, посебно место где је жртвован, које личи на позорницу где су Пљевљак и тројица Цигана симболи хтонских предела смрти. ${ }^{4}$

После страдања Радисава почиње друга врста жртве. Од овог момента у свакој кући појачана је молитва, горе кандила као жртвовање Богу, али и као традиционално кађење покојника. (Тројановић 1990: 219) Жене су почеле да шапућу молитву: „Помози нас, Боже, ти Једини, потри душманина и не дај му дуге власти“. (Андрић 1991: 151) После ове жртве нешто се у свести народа догодило. Човек на коцу, како каже Андрић, „постао је општа брига и светиња“. (Андрић, 1991: 151) Било је важно положити тело у земљу, ${ }^{5}$ „снагом сажаљења и древних обичаја“. (Андрић, 1991: 151) Сахрана покојника била је важан део обреда прелаза (Генеп 2005: 35.53) и она припада сфери древног веровања да семе положено даје род. У том правцу би тре-

4 „На уским пролазима од греда и дасака сејмени су потпуно окружили и стисли међу собом Радисава, да им не би скочио у реку. Тако су се провлачили полако и пели све више док не дођоше до краја. Ту је над водом био попођен простор у величини једне осредње собе. На том простору се, као на уздигнутој позорници, сместише Радисав и тројица Цигана, остали сејмени остадоше растурени наоколо по скелама." Иво Андрић, На Дрини ћуйрија, Просвета, БИГЗ, СКЗ, Нолит, Београд1991, стр. 143.

5 „Дарови мртвима и обичаји везани за сахрањивање показују да је још од давнина човек имао неко веровање о даљем животу својих мртвих. Спонтани и митски концепт који древни човек има о земљи чини се да осећај даљег живота сахрањених-сачуваних наставља у очекивање поновног рађања. Том поновном рађању на земљи сачувана лобања треба да буде путоказ. Поновно изникло тело спаја се са својом лобањом и поново живи као целина у овостраном или оностраном животу“. Миодраг Павло-

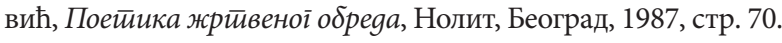


бало и посматрати готово сакралну бригу народа да се тело положи у земљу. Андрић је потенцирао важност полагања тела у земљу и неопходност овог последњег обреда прелаза. На тај начин указао је на важност не само хришћанског, већ и претхришћанског обреда сахрањивања, односно полагања тела у Велику Мајку. До овог момента жртва (мртворођени близанци) принета је камену да би опстао, затим земљи да би прихватила диреке моста, а како се радови нису одвијали на води, било је потребно принети жртву владару воде. Занимљиво је да је највећа жртва у роману, Радисав, сахрањен „ту, у једној удолини коју су створиле пролетње и јесење воде јурећи са брега ка Дрини“. (Андрић, 1991: 154) Дакле, на оном месту где су воде које хитају ка Дрини. Тело је испраћено по хришћанском обреду. Људи пале свеће, а „сељак затим махну двапут изнад мртваца руком као да га прелива из празне руке невидљивим вином и двапут изговори тихо и скрушено: -Со свјатими упокој, Христе, душу раба твојего“. (Андрић, 1991: 154) Изговарање свечаних речи упућује на обредност и хришћанску жртву, али је укључен и моменат из словенске митологије, јер су жене причале да су несрећног Радисава сахраниле виле ${ }^{6}$. Андрић каже да се после ове жртве посао на мосту „настављао брзо и глатко, без прекида и поремећаја“"(Андрић, 1991: 156), док се опет није успорило због хладне зиме. Очигледно је да ни све жртве земљи и води нису биле довољне. Сва жртвовања до овог тренутка била су довољна само да се укроти вода чија је судбина, како каже Мирча Елијаде, „да претходи Стварању и да га у себе упија, неспособна да надмаши сопствени начин бивствовања, то јест да испољи сопствене облике“. (Елијаде

6 „Међу Србима на мејдану, жене су причале како су виле сахраниле мртво тело несрећног Радисава под Бутковим стијенама, и како ноћу пада с неба обилна светлост на његов гроб: хиљаде хиљада запаљених свећа које пламсају и дрхте, у дугом низу од неба до земље. Виделе су их кроз сузе“. Иво Андрић, На Дрини ћуйрија, стр. 156. 
1991: 157) И после неколико принетих жртава моста није било.

Андрић констатује да ће се догодити још једна несрећа, али она „без којих велике грађевине ретко бивају“. (Андрић, 1991: 160) Наиме, догодиће се смрт и сахрана Арапина, уз исламски обред, и подизање нишана на гробу. Принета је још једна жртва, али сада, уз строго обављени последњи обред прелаза. Андрић каже да је Арапинова сахрана била „свечан догађај који се дуго памтио“. (Андрић, 1991: 160) Овде је успостављена обредна жртва која у себи има елементе имитативне магије. Жртва исламске вероисповести (Абидага) је положена у уземљу, а нишан је направљен „од камена од којег се мост гради“ (Андрић, 1991: 161) Ово је још један облик жртвовања камена, што потврђује став Миодрага Павловића да је „парадокс камена-створа родио (је) могућност да се адресант жртве прошири у просторе неба и земље, а да од првобитног идола (камена) постане једна сведена функција: жртвеник“. (Павловић 1984: 22)

После пет година указао се мост „на једанаест моћних лукова, савршен и чудан у својој лепоти, као нов и стран предео за касаблијске очи“. (Андрић, 1991: 162) На крају градње Андрић је поново прибегао симболичној замени за жртву, а то је гозба у којој је садржано не само обедовање, као саставни део свих обреда, па и жртвених, већ и игра, свирка и песма, као и обредно даривање: „Јело се, пило, свирало, играло и певало; приређене су коњске и пешачке трке; сиротињи су дељени месо и слаткиши“. (Андрић, 1991: 163) Ову обредну прославу, за коју писац каже да су полако ишчезавале ставља „у исти ред са легендама о вилама, о Стоји и Остоји, и сличним чудима“. (Андрић 1991: 164) Андрић круг жртвеног обреда, потребног за опстанак моста, завршава гозбом. Занимљиво је да писац посебно место даје колу ${ }^{7}$ које игра на мосту, са

„Турски момци су заметали коло око казана са халвом, водили га преко моста, јер ту им се чинило да лете а не да земљу газе, па 
посебним нагласком на игру момака, који на неки начин поново представљају симболичну замену за жртву, јер је у традиционалној култури Срба коло имало посебно значење. Коло, као симбол спајања са небеским, соларним принципом, у традицији има и функцију терања демона. Занимљиво је да је у току играња присутна стална мисао на Арапина која изазива страх, али је у овом споју супротности Андрић и био на трагу митолошког доживљаја света у којој је непрестана борба светлости и таме.

У систем обредног жртвовања Андрић је увео и жртвовање невесте „да појача жртвени карактер елемената којом се жртва обраћа (земља, вода)“. (Павловић 1987: 63) Фатимино самоубиство, важан је моменат у систему жртвовања зато што је добровољна, зато што невеста није потрошила своју снагу на ерос (што је основно правило обредне жртве) и зато што се жртвовање догађа на мосту, и то у његовом средишњем делу, на капији („то није ни први ни последњи пут да сватови застају на капији“. (Андрић 1991: 212)) Њено жртвовање догађа се пред народом, оно подсећа на ритуално жртовање води, као део словенског пролећног обреда везаног за вегетацију. Невеста Фатима се жртвује добровољно. Она данима смишља одвајање од сватова и скок у воду, која је годинама савладавана силама овога и онога света. Овде налазимо и један скривени моменат који бисмо могли повезати са моделом жртвовања које захтева жртвовање

затим савијали уокруг на капији и ту су трупкали и били ногама о нове плоче као да искушавају тврдоћу моста. Око тога сабијеног, округлог кола младих телеса која неуморно поскакују све у истом ритму, обигравали су дечаци протрчавали између разиграних ногу, као кроз помични плот, стајали у средини кола, први пут у животу на мосту о којем се већ годинама говори, и то на капији за коју се каже да је у њој затворен онај несрећни покојни Арапин и да се ноћу приказује. Уживајући у момачком колу они су и премирали од страха који је Арапин и док је жив био и радио на мосту непрестано уливао касаблијској деци.“ Иво Андрић, На Дрини ћуӣрија, стр. 164. 
браће и сестре. Како је ово најчешће правило обредног жртвовања, Андрић ће на мосту, на тренутак, фокусирати брата ${ }^{8}$ и сестру, у тренутку њеног одласка у смрт. Брат није жртвован, али је и он, жртвовањем сестре, ушао у симболични систем жртвовања.

Како су у градњи моста испоштовани сви облици ритуалне жртве, деце, брата и сестре, мушког и женског принципа, невесте, најбољег представника рода и хришћана и муслимана, на крају, у обедном жртвовању Андрић ће констатовати да је ово био надчовечански напор, „као да је поред досад познатих елемената: земље, воде и неба, откривен одједном још један...да се иде изнад воде и савлађује простор“. (Андрић 1991: 164) Андрић је у свој роман транспоновао богате облике традиционалне културе чије архетипске слојеве налазимо нарочито у обредно-обичајној пракси која је била важан елеменат у изградњи моста на Дрини. Укључујући у градњу моста различите облике митолошке слике света Андрић је у свој роман транспоновао обреде из традиционалне културе Срба, а скоро „сви обреди“, како наводи Мирча Елијаде „призивају йочейак, Митско време када свет још није постојао“. (Елијаде 1991: 121) Митолошки слојеви приповедања оквир су времена у које се смешта градња моста, а који се, као какво живо биће, „не мења ни са годинама ни са столећима, ни са најболнијим променама људских односа“. (Андрић 1991: 201)

8 „Док је брат сјахао, заобишао коња и пребацио узду преко руке, девојка је притерала свога на сам крај моста, ступила десном ногом на камену ограду, винула се, као окрилатила, са седла, преко зида, и полетела са висине у хучну реку под мостом. Брат који се устремио за њом и целим телом полегао по огради још је дотакнуо руком узвитлану фереџу, али је задржати није могао. Остали свати су поскскали са коња са најнеобичнијим узвицима и остали поред камене ограде, у чудним положајима, као скамењени“. ИвоАндрић, На Дрини ћуӣрија, стр. 212. 
Градња моста и жртвени обред у роману На Дрини ћуйрија... 153

Извори и литература

Андрић, Иво. На Дрини ћуйрија, Београд, Просвета, БИГЗ, СКЗ, Нолит, 1991.

Генеп, Ван. Обреgи ӥрелаза,Београд, СКЗ, 2005.

Делић, Лидија. Сукоб јунака с ииновком у јужнословенској усменој ейиนи, у „Српско усмено стваралаштво у интеркултурном коду“, Београд, Институт за књижевност и уметност, 2012.

Елијаде, Мирча. Светио и йрофано, Сремски Карловци, Нови Сад, Издавачка књижница Зорана Стојановића, 2003.

Зечевић, Слободан. Кулй мрйвих коg Срба, Београд, 1982.

Зечевић, Слободан. Мийска бића срииских йреgака, Београд, Службени гласник, 2007.

Јанићијевић, Јован. У знаку Молоха, Београд, Вајат, 1986.

Нојман, Ерих. Ист̄оријско йорекло свестии, Београд, Просвета, 1994.

Павловић, Миодраг. Прирояни облик и лик, Београд, Нолит, 1984.

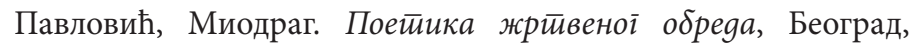
Нолит, 1987.

Самарџија, Снежана. Биографије епских јунака, Београд, Друштво за српски језик и књижевност Србије, 2008.

Срйски митиолочки речник, Ш. Кулишшћ, П. Ж. Петровић, Н. Пантелић, Београд, Нолит, 1970.

Тројановић, Сима. Ватра у обичајима и животу српског народа, Београд, Просвета, 1990.

Фрејзер, Џејмс Џорџ. Злайна ірана, Београд, БИГЗ, 1992.

Чајкановић, Веселин. Сйара срӣска релиіија и мийолоіија, Београд, СКЗ, БИГЗ, Просвета, Партенон М. А. М, 1994

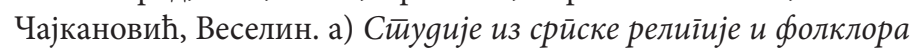
1925-1942, Београд, СКЗ, БИГЗ, Просвета, Партенон М. А. M, 1994.

Џаџић, Петар. „Иво Андрић: легенда, прича, мит, историја“, Предговор, у Иво Андрић, На Дрини ћуирија, Београд, Просвета, Београд, БИГЗ-СКЗ-Нолит, 1991. 


\section{Valentina Pitulić}

\section{THE CONSTRUCTION OF THE BRIDGE AND SACRIFICIAL RITE IN IVO ANDRIĆ'S NOVEL THE BRIDGE ON THE DRINA}

In this paper, we will address the issue of the construction of the bridge on the Drina River in the light of sacrificial rite, which was an established act in ancient times that has conditioned the survival of each construction. As all ancient civilizations cherished ritual and customary practices, through which the contact with the beyond was achieved, we will indicate the way in which Ivo Andrić corresponds with the remains of archaic layers in the collective-unconscious layers of the bridge builder in his novel The Bridge on the Drina.

Bearing in mind that the entire novel tells the story about the bridge, we will demonstrate to what extent the sacrificial rite, as a key moment in the life of the Slavic nation, had effect on the survival of the bridge. It is quite interesting to observe the way in which Andrić incorporates the remains of sacrificial rituals into his text and how it affects the plot of the novel. Sacrificial rite, as a complex act, is subject to strictly defined rules that must be met in order to preserve the structure. We will demonstrate whether the writer has transposed, within his novel The Bridge on the Drina, an already established model of sacrificial ritual that has long lived in the collective consciousness of the Serbs. In this paper, we will deal with those layers that have contributed to the construction of the bridge, which are located in the subtext, are difficult to detect, and make an integral part of the ritual that affects the survival of the structure.

Key words: sacrifice, ritual, bridge, Drina, initiation, structure, collective. 